\title{
NAPELEMEK ENERGIATERMELÉSÉNEK VIZSGÁLATA
}

\author{
Rozsnyai Gábor \\ MSc hallgató, Miskolci Egyetem, Gépészmérnöki és Informatikai Kar \\ Automatizálás és Infokommunikációs Intézet \\ 3515 Miskolc, Miskolc-Egyetemváros, e-mail: qgergabi@uni-miskolc.hu
}

\begin{abstract}
Absztrakt
A cikkem a mai fejlödö világban eléggé népszerüvé váló napelemekröl szól, hogy és miként épülnek fel szerkezetileg, milyen anyagokat használnak fel egy ilyen szerkezethez, valamint hogyan állít elö napsugárzásból tiszta villamos energiát. Továbbiakban szó lesz a napelemek teljesitményéröl és villamos energia termeléséröl. A vizsgálat egy létezö napelemes rendszer méréseit és eredményeit tartalmazza.
\end{abstract}

Kulcsszavak: napelem, kristályos szilícium, teljesitmény mérés

\section{Abstract}

My article is about solar cells, which are becoming quite popular in today's developing world, how they are structurally constructed, what materials are used for such a structure, and how they generate clean electricity from solar radiation. In the following, we will discuss the performance of solar panels and the generation of electricity. The study includes measurements and results from an existing solar system.

Keywords: solar panel, crystalline silicon, power measurement

\section{Bevezetés}

A napenergia a napból származó hő és fény együttese, melyet a nap a föld felé bocsájt ki sugárzás formájában. A napenergiát megújuló energiaforrásként tartják számon, amely mindig rendelkezésünkre áll, ez részben igaz is, mert a napsugárzás mindig létezik. Ha fix telepítésủ eszközön gondolkodunk, azon a helyen a nap nem mindig süt, az esti órákban nincs napsugárzás, és évszaktól is függ, ugyanis késő tavaszi és kora őszi hónapokban jobb a hatásfok.

A napenergia a földi élet energetikai alapja, mivel a geotermikus energián kívül minden megújuló energiának a Nap a forrása, amelynek magjában lejátszódó magfúziós folyamat szolgáltatja a Nap által kibocsátott, sugárzott energiát. Bár a földi élet szempontjából a legfontosabb a Nap elektromágneses sugárzása (390-1.200 nm), ennek csupán kis részét érzékelhetjük közvetlenül hő (800-1.200 nm) és fény (390-800 nm) formájában. Az emberiség által leggyakrabban használt, fosszilis energiaforrások mennyiségi korlátját figyelembe véve, a megújuló energiák, mint például a napenergia hasznosításának kérdése igen időszerü témának bizonyul napjainkban.

A napenergia hasznosítása történhet aktív, vagy passzív módon. Passzív napenergia hasznosítás esetén épületek energetikailag kedvezőbb irányú tájolásáról beszélünk, amivel csökkenthetjük az épület energiaszükségleteit. A napenergia aktív hasznosításához valamilyen eszközre van szükségünk, amellyel felfogjuk, illetve átalakítjuk a Nap energiáját, így környezetbarát módon állíthatunk elő villamosenergiát, vagy közvetlenül hőenergiát, attól függően, hogy napelemet, napkollektort, vagy 
napkohót alkalmazunk. Utóbbi két eszköz a Nap energiáját, hőjét gyüjti össze nagyobb hatékonysággal és hőenergiaként továbbítja azt. Leggyakrabban melegvíz előállításra használják őket olyan területeken, ahol napközben hosszú és intenzív a napsütés, de akár fütés rásegítő szerepet is betölthetnek [1].

\section{Múködési elv}

A napelem fényt alakít át villamos energiává, ezt 3 lépésben képes megvalósítani: fényelnyelés, a töltések szétválasztása, a felhalmozott töltések továbbítása külső áramkörbe.

Fényelnyelés: idegen nevén abszorpció esetén a gerjesztett állapotú elektron a vezetési sávba kerül, amíg a lyuk a vegyérték sávba. A tiszta félvezetők nagyon nagy abszorpciós tényezővel rendelkeznek, az abszorpciós sávjukban.

Töltésszétválasztás: A félvezető belsejében az elektronok és lyukak szétválnak a PN átmenetben. Más mechanizmusok is ismertek, mint például az alagút effektus, ilyenkor az elektronok képesek áthaladni egy vékony szigetelő rétegen.

Töltésvezetés: A napelem két oldala között a töltésszétválasztás miatt potenciál különbség lép fel. A töltések elvezetését kontaktusokkal lehet megoldani, bár ez nem egyszerü feladat, ugyanis a kontaktusoknak nagyon kicsi ellenállásúaknak kell lenniük, hogy a veszteségek minél kisebbek legyenek. A kimenő villamos teljesítmény optimális értékének eléréséhez megfelelő abszorber réteget kell kiválasztani a fény frekvenciájának megfelelően [5,6].

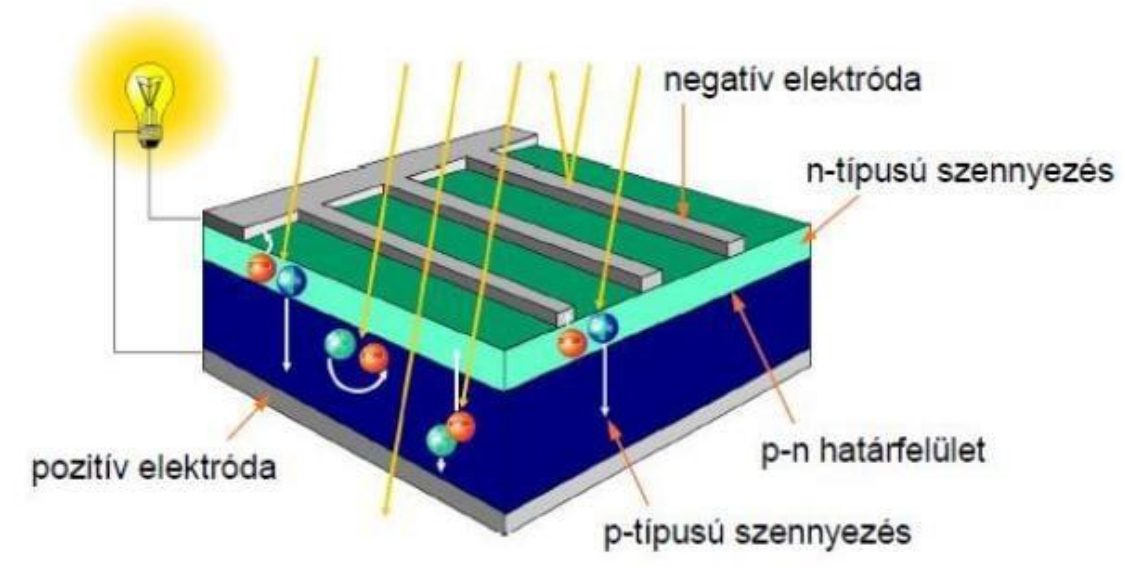

1. ábra Kristályos szilícium napelem [5]

\section{Spektrális érzékenység}

A félvezetők abszorpciós sávja jóval kisebb, mint a napból érkező fény spektruma, ez az egyik ok, ami lekorlátozza a hatásfokot. Megoldás erre problémára, hogy nem egyetlen egyszerü elemből kell megépíteni a napelemet, hanem több anyag kombinációjából kell készíteni. Erre a megoldásra, több technikát is kifejlesztettek, az első ilyen az egymásra helyezés volt, ezután következtek a bonyolultabb kivitelezések egészen az elemek egyazon hordozóra való felviteléig (2. ábra) [5]. 


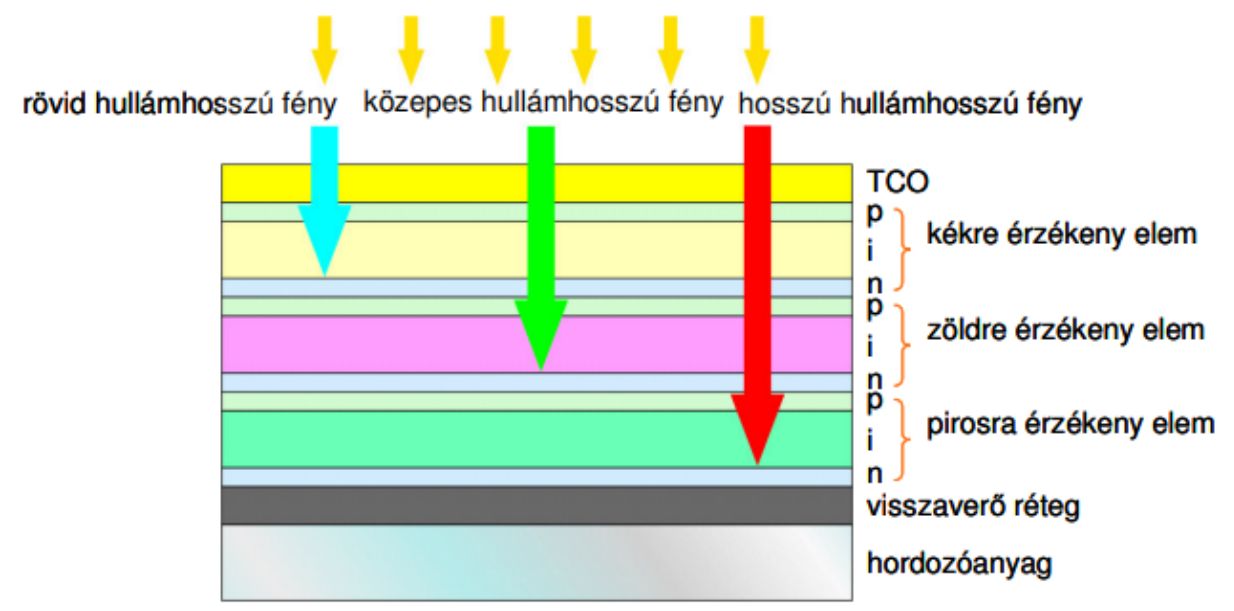

2. ábra Különbözö anyagok kombinációjából készitett napelem [5]

\section{Solar Decathlon}

A Solar Decathlon Europe egy Európában megrendezett egyetemek közötti nemzetközi innovációs házépítő verseny, amely arra hivatott, hogy népszerüsítse a napenergiával és más megújuló energiával müködő passzív házakat. A publikációban vizsgált napelemes rendszer ezen a rendezvényen a Someshine csapat által megépített házon található. A napelemek elrendezése:

- Nyugati oldalon: 5 db vertikális 31 fokos dölésszög

- Déli oldalon: 5 db vertikális, 2 db horizontális 34 fokos dölésszög

- Keleti oldalon: $5 \mathrm{db}$ vertikális, 2 db horizontális 31 fokos dőlésszög A napelemek mérete $1 \mathrm{~m} * 1,6 \mathrm{~m}$, tehát a felületük 1,6 $\mathrm{m}^{2}$, a napelemes rendszer hálózatra tápláló.

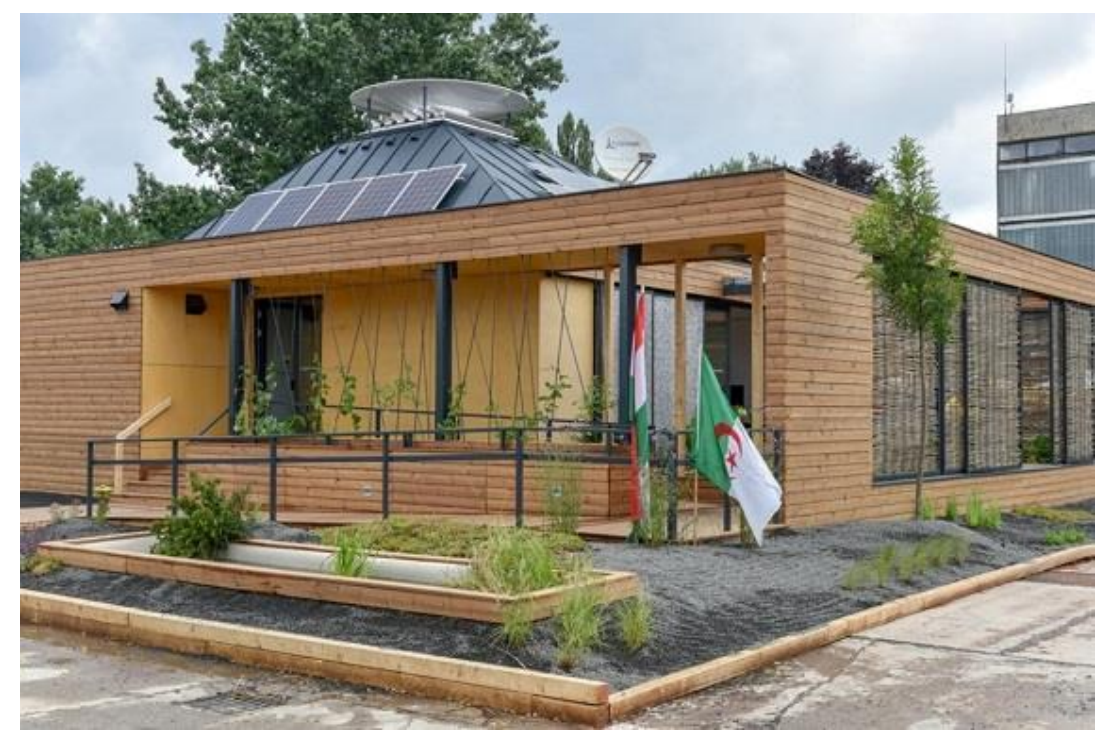

3. ábra Someshine csapat által megépített ház 


\section{Teljesítmény és energiatermelés}

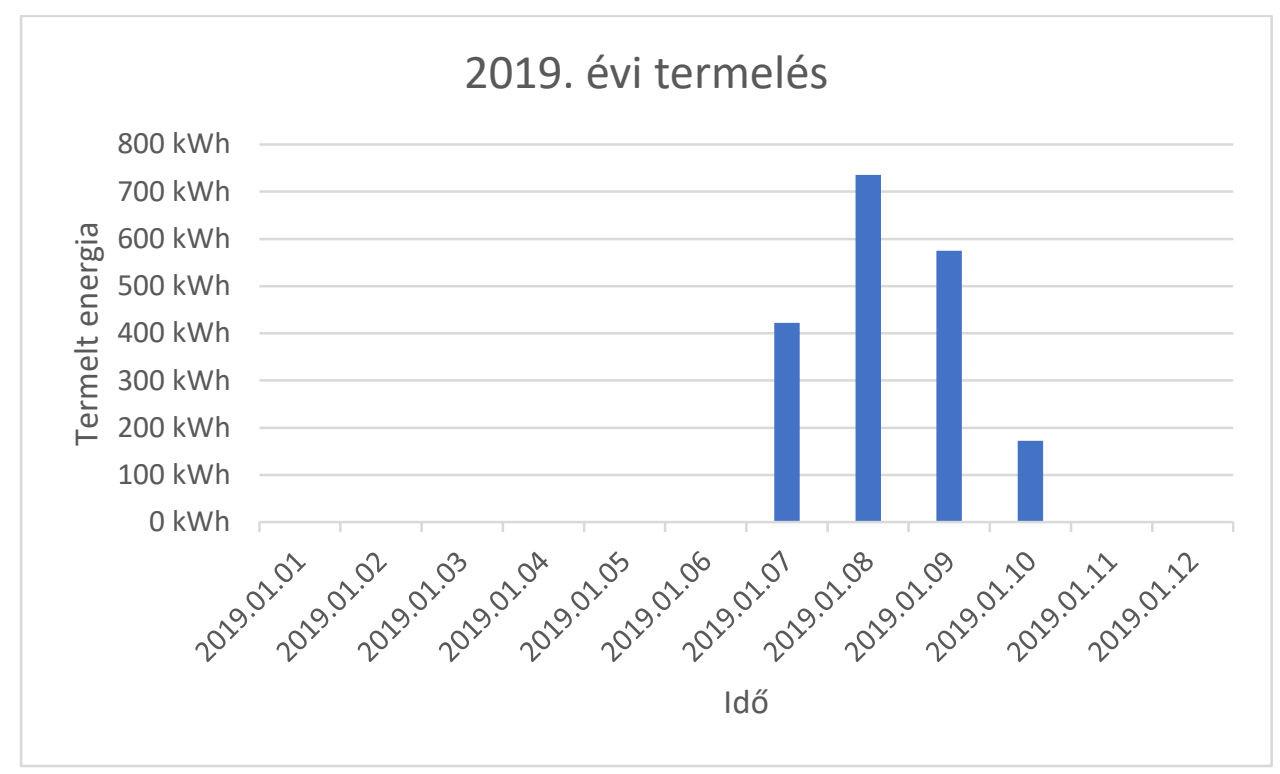

4. ábra 2019-es év energia termelése

A 4. ábrán a 2019-es év villamosenergia termelését $(\mathrm{kWh})$ láthatjuk az idő függvényében. A termelés 2019. júliusában kezdődött és a napelemeket októberben kapcsolták le a hálózatról. A termelés augusztus hónapban érte el a maximumot, a minimum pedig októberben mutatkozott az ábra szerint, ez betudható annak, hogy a rendszert 2019. október 11.-én lekapcsolták a hálózatról, így abban a hónapban csak 11 napon keresztül volt aktív.

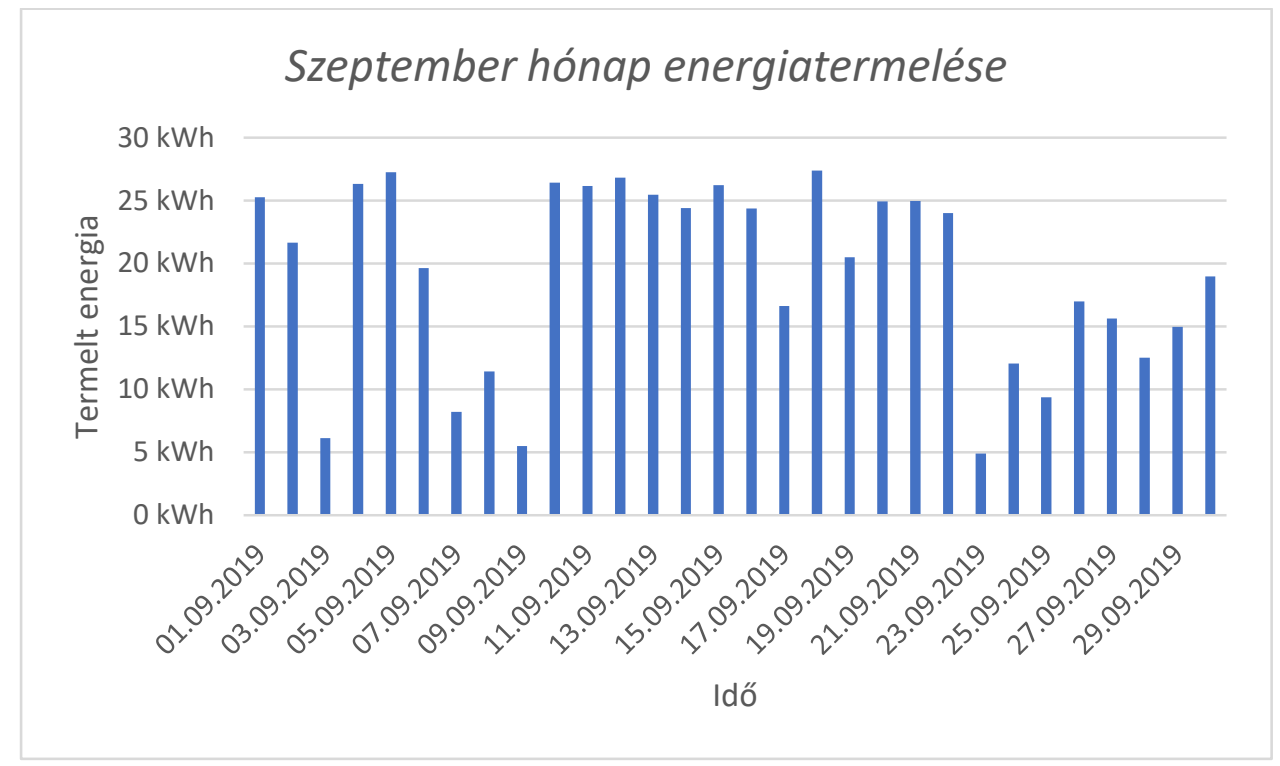

5. ábra Szeptember hónap energiatermelése 
Az 5. ábrán szeptember hónap energia termelését láthatjuk napokra bontva. Megfigyelhető, hogy szép napos időben a napelemes rendszer energia termelése $25 \mathrm{kWh}$. Előfordul, hogy az időjárás nem kedvező a rendszernek pl: felhő képződés, ilyenkor a termelés $5 \mathrm{kWh}$ értékre is képes lecsökkenni, ez a kedvező időjárás termelésének $20 \%$-a, tehát a termelés jelentősen le tud esni, ha nem kedveznek az időjárási viszonyok.

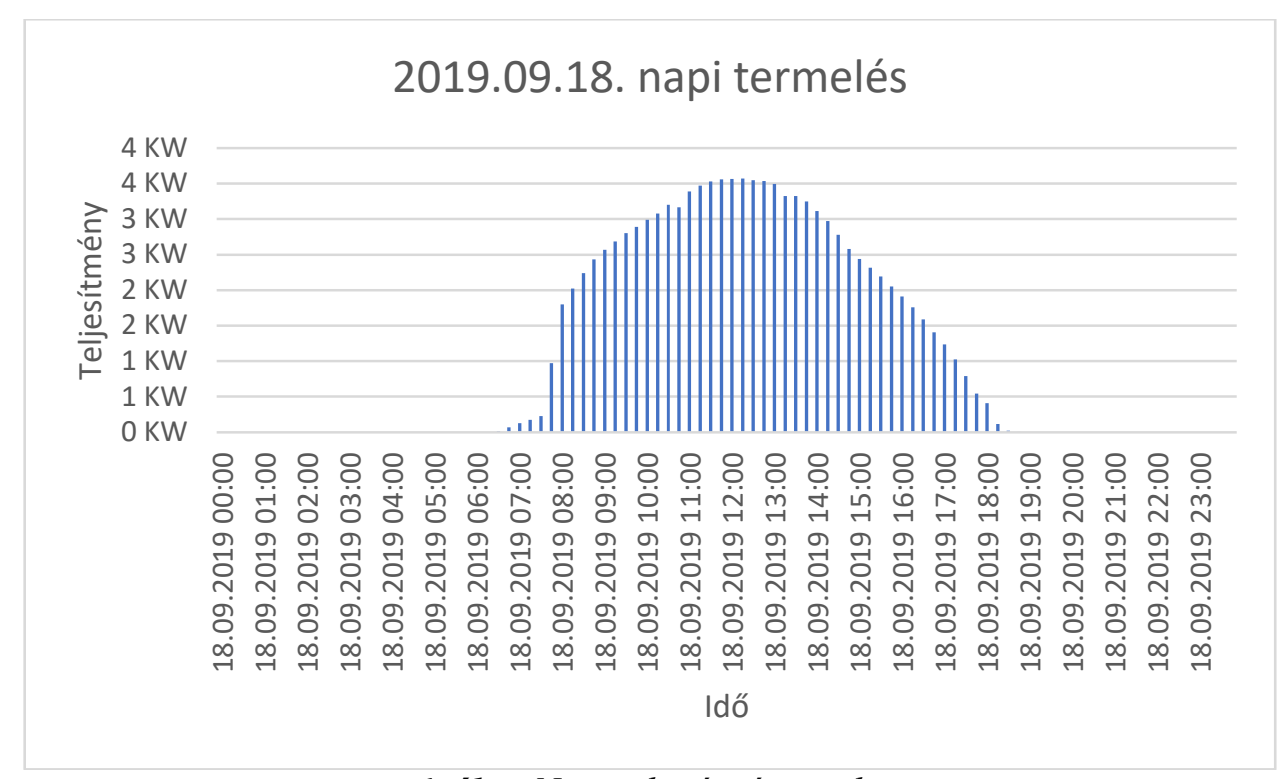

\section{6. ábra Napi teljesitménygörbe}

A 6. ábrán egy szeptemberi nap teljesítmény görbéjét figyelhetjük meg. A vízszintes tengelyen az idő, amíg a függőleges tengelyen a teljesítmény $(\mathrm{kW})$ látható. Napfelkeltekor csak a ház keleti oldalán elhelyezett napelemek vesznek részt a termelésben, majd később a nap elörehaladtával bekapcsolódnak a többi oldalon lévő napelemek is. Napnyugtakor a teljesítménygörbében egy lineáris csökkenés figyelhető meg, ilyenkor a nap beesési szögének változása miatt szintén csökken a teljesítmény, tehát ha csökken a nap beesési szöge a teljesítmény is monoton csökkenni fog.

\section{Teljesítmény vizsgálat és teljesítmény mérleg}

A megfigyelés szemléletesebb lenne, ha egyszerre tudnánk a napelemeink által termelt energiát és a háztartási fogyasztást ábrázolni. Erre megoldás, ha a fogyasztóinkat is elkezdjünk figyelni egy eszközzel, amely méri a felvett teljesítményüket. Ha ezek a feltételek teljesülnek, akkor képesek vagyunk egy teljesítménymérleget összeállítani, ami megmutatja, hogy a termelésünk vagy a fogyasztásunk a magasabb.

- Ha rendszerünk a termelt energia felé billen, akkor az azt jelenti, hogy a napelemünk energia termelése meghaladja azt a mennyiséget, amelyet a fogyasztunk, megjelenik az export.

- Ha pedig az ellenkezője felé billen a mérleg, akkor a napelem által termelt energia nem fedezi teljes egészében a fogyasztásunkat, szükségünk van importra. 
- Persze létezik egy harmadik állapot, ami elég ritka, ilyenkor a mérleg egyensúlyban van, tehát a termelés és fogyasztás megegyezik.

Pozitív teljesítménymérleg:

Negatív teljesítménymérleg:

$$
P_{\text {napelem }}=P_{\text {fogyasztók }}+P_{\text {export }}
$$

$$
P_{\text {fogyasztók }}=P_{\text {napelem }}+P_{\text {import }}
$$

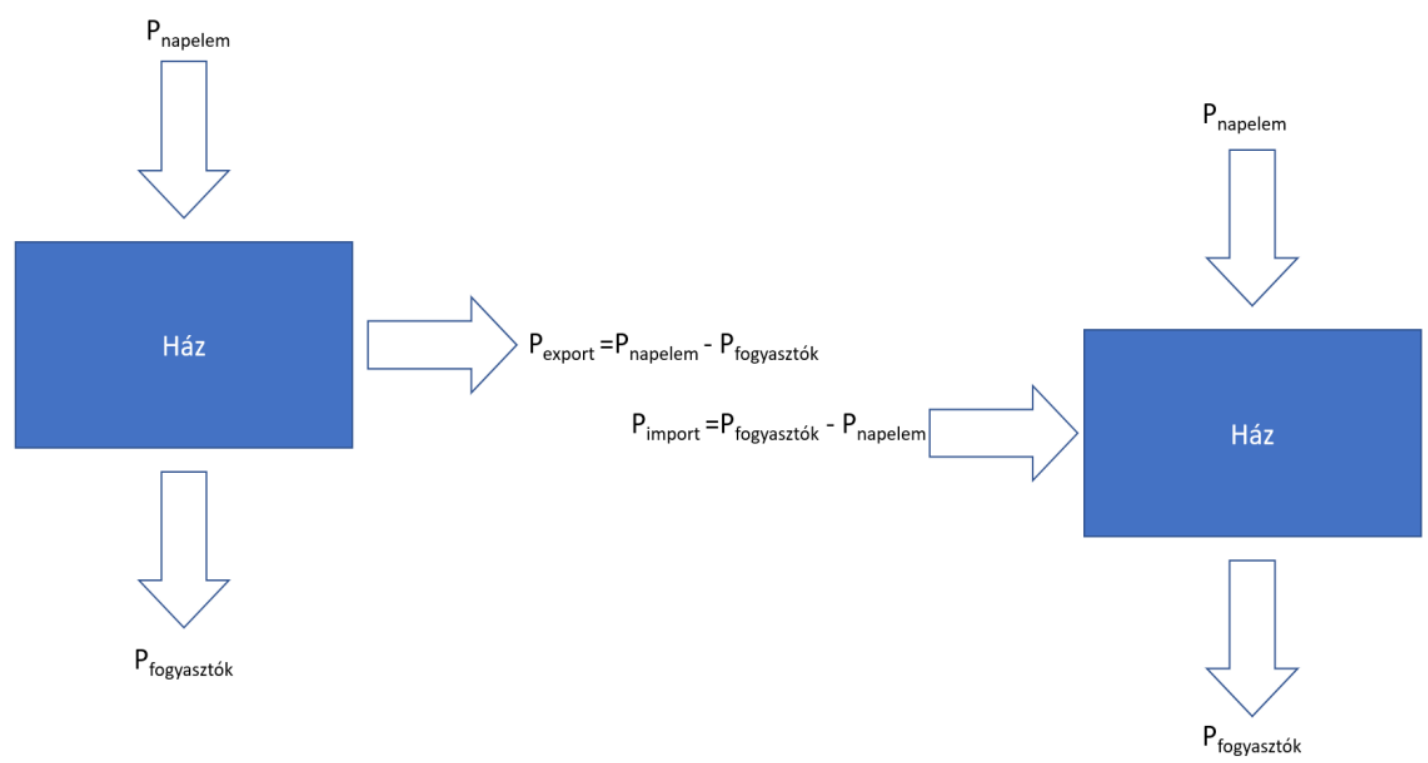

7. ábra A ház teljesitménymérlegének két esete

A villamos fogyasztók teljesítményének mérésére egy opció a Wago cég által forgalmazott 3 fázisú mérőmodul, melynek típusszáma 750-495. Ez az eszköz képes feszültséget, áramot és teljesítményt mérni, valamint egy szoftver segítségével egy olyan felületet kapunk, ahol valós időben tárulnak elénk az adatok, valamint naplózni is képes ezeket az értékeket. A jövőbeli célok közé tartozik egy ilyen rendszer telepítése, amely a fogyasztók irányában történő méréseket végzi, ezért nem csak a napelem felől érkező adatokat leszünk képesek megvizsgálni, hanem a fogyasztók oldaláról is. Ezekkel az adatokkal képesek leszünk egy teljesítmény valamint energia mérleg felvételére is, amelyek elég szemléletesek.

\section{7. Összefoglalás}

A napenergia, mint megújuló energiaforrás nagyszerű irányzat a zöld energia elóállítása felé. Kellő mennyiségű napelemmel képesek vagyunk fedezni egy családi ház villamosenergia fogyasztását tisztán a napsugárzás energiájából. A cikkben szereplő mérési adatok szerint a napelemes rendszer jobban teljesít ősszel, mint a forró nyári napokon, ez annak tudható be, hogy a napelemek melegedése ront a rendszer hatásfokán. A napelemek kiválasztása és elhelyezése is fontos szerepet játszik a hatásfok növelésében, a megfelelő dőlésszög és a tájolás kiválasztása is. 


\section{Köszönetnyilvánítás}

A cikkben ismertetett kutató munka az EFOP-3.6.1-16-2016-00011 jelű „Fiatalodó és Megújuló Egyetem - Innovatív Tudásváros - a Miskolci Egyetem intelligens szakosodást szolgáló intézményi fejlesztése" projekt részeként - a Széchenyi 2020 keretében - az Európai Unió támogatásával, az Európai Szociális Alap társfinanszírozásával valósul meg.

\section{Irodalom}

[1] Skribanek, Á. Napelemek közbeiktatásával kialakított szünetmentes villamosenergia-ellátó rendszer vizsgálata.

[2] Archer, M.D., Hill, R. Clean Electricity from Photovoltaics. Imperial College Press, 2001. https://doi.org/10.1142/p139

[3] Bodnár, I. Napelem hőmérsékletfüggésének kísérleten és szimuláción Alapuló vizsgálata". Jelenkori társadalmi és gazdasági folyamatok 2017, 2(4):195-206. https://doi.org/10.14232/jtgf.2017.4.195-206

[4] Kovács, Cs. Napelemek működése és alkalmazásai. Budapest. 2008.

[5] Ármin, R. Napelem technológiák és jellemzőik. PSE Projektgesellschaft Solar Energiesysteme GmbH. 2004.

[6] Bodnár, I. Napelem müködésének alapjai, a napelemes villamosenergia-termelés elmélete és gyakorlati megvalósítása. Miskolc, Miskolci Egyetem Elektrotechnikai és Elektronikai Intézete. 2019. ISBN 9786150045665 